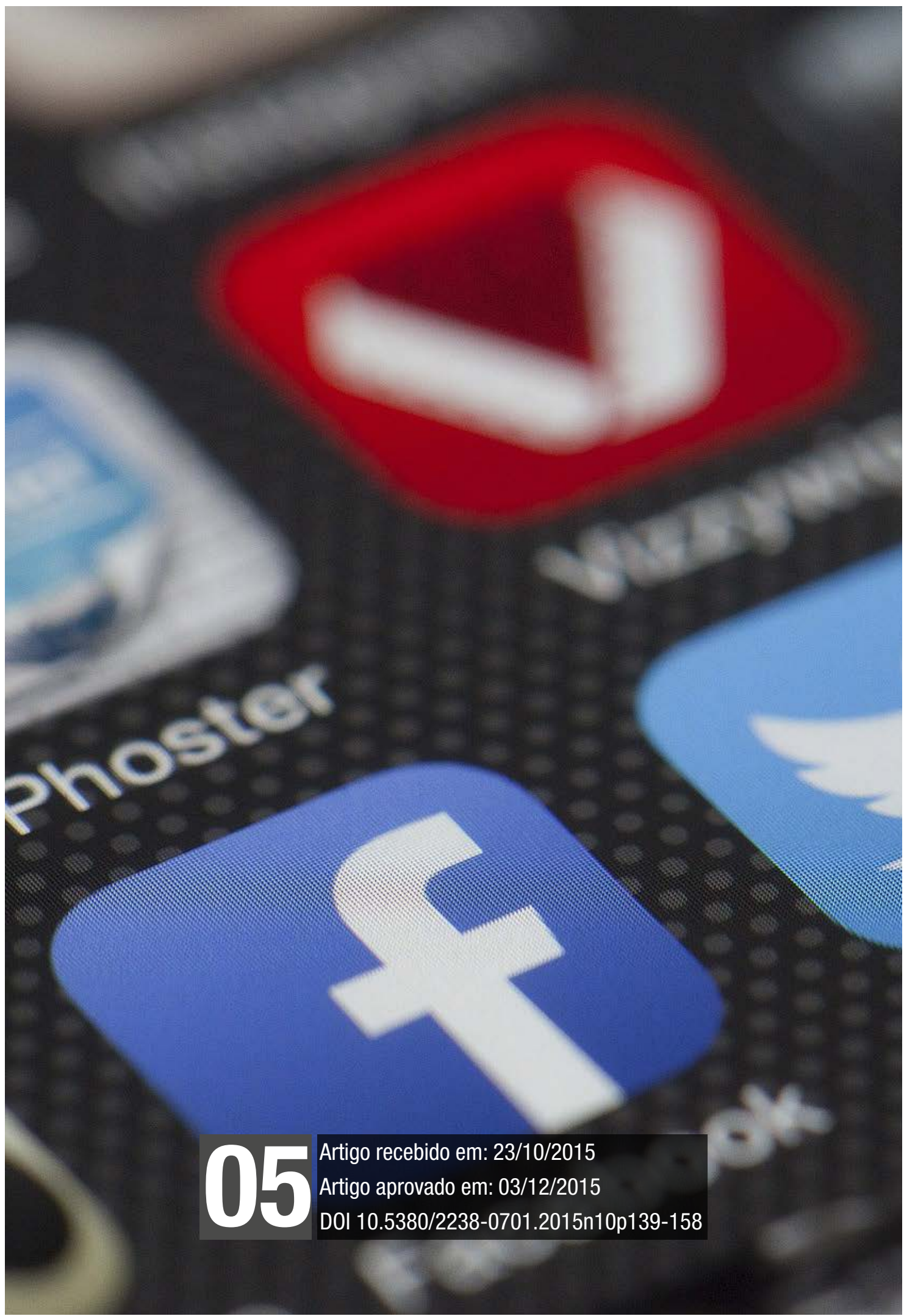


AÇÃO MIDIÁTICA, n. 10. Jul/Dez. 2015. Curitiba. PPGCOM-UFPR. ISSN 2238-0701 


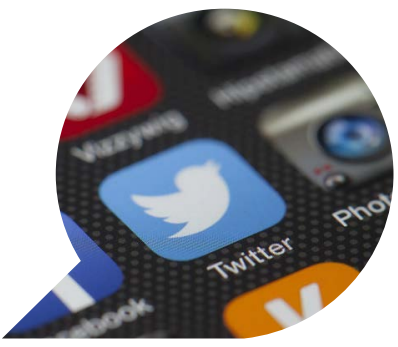

\title{
Ensino de jornalismo e novas práticas jornalísticas no século XXI: globalização, sociedade e tecnologia
}

\author{
Journalism education and new journalistic \\ practices in the XXI Century: globalization, \\ society and technology
}

Educación en periodismo y nuevas prácticas periodísticas en el siglo XXI: globalización, sociedad y tecnología

\begin{tabular}{c}
\hline ALINE TAINÁ AMARAL HORN $^{*}$ \\
\hline LUIS OTÁVIO DIAS $^{* *}$ \\
\hline ROSA MARIA CARDOSO DALLA COSTA $^{* * *}$
\end{tabular}

\footnotetext{
* Jornalista e mestranda do Programa de Pós-Graduação em Comunicação da Universidade Federal do Paraná (PPGCOM), linha de pesquisa Comunicação, Educação e Formações Socioculturais. E-mail: hornaline@gmail.com

** Doutorando do Programa de Pós-Graduação em Educação da Universidade Federal (PPGE). Professor de Jornalismo do Centro Universitário Internacional Uninter Curitiba/PR. E-mail: fototavio@yahoo.com.br

*** Prof. - Dr. - do Programa de Pós-Graduação em Comunicação e Educação da Universidade Federal do Paraná (PPGCOM/PPGE). Jornalista (MT 16792/65/54) e Advogada (OAB/PR 67.414). Doutora em Sciences de l'Information et de la Communication (Université de Paris VIII, 1999) e Pós-Doutora em Comunicação pela Maison des Sciences de l'Homme - Paris Nord (2008). E-mail: rmdcosta@uol.com.br
} 
Resumo: $\mathrm{O}$ artigo propõe a discussão sobre o ensino de Jornalismo e as perspectivas de atuação do jornalista frente às mudanças latentes na sociedade globalizada, diante do impacto da cultura digital, dos novos modos de interação com o público e questões de ordem institucional e mercadológica, em um momento de adaptações dos cursos de Jornalismo no Brasil com as Novas Diretrizes Curriculares. O estudo, em fase de desenvolvimento, faz parte de uma pesquisa sobre as novas práticas jornalísticas, que integra um grupo internacional de investigação sobre o tema. Tem como objetivo discorrer sobre o campo de convergências e dicotomias entre o ensino do jornalismo e a prática profissional dos jornalistas que trabalham na redação do portal de notícias web, Brasil Post. Encontra pressupostos teóricos em Bauman (1999), Wolton (2011) e Mattelart (2005) para discorrer sobre o tempo, o espaço e as Novas Tecnologias da Informação e da Comunicação e, ancora-se em Fígaro (2013) para discorrer sobre o modo de fazer jornalismo no século XXI.

Palavras-chave: Ensino do jornalismo; Jornalismo digital; Novas tecnologias da informação e da comunicação.

Abstract: This article proposes the discussion about journalism education and perspectives of work of the journalist in the face of latent changes in global society, the impact of digital culture, new ways of interaction with the public and issues of institutional and market order in a time adjustments of journalism courses in Brazil with the New Curriculum Guidelines. This study has been developed and is part of a research on new journalistic practices, part of an international group of research on the topic. It aims to discuss the convergence field and dichotomies between journalism education and practice professional journalists working in the web news portal, Brazil Post. Is theoretical assumptions Bauman (1999), Wolton (2011) and Mattelart (2005) to understand the time, space and New Technologies of Information and Communication and is anchored in Fígaro (2013)) to discuss how to do journalism in the XXI century.

Keywords: Journalism education; Digital journalism; New information technologies and communication. 
Resumen: En este artículo se propone la discusión sobre la educación y las perspectivas de trabajo de la periodista en la cara de los cambios latentes en la sociedad global de periodismo, ante el impacto de la cultura digital, las nuevas formas de interacción con el público y los problemas de orden institucional $y$ de mercado en un ajustes de tiempo de los cursos de periodismo en Brasil con las nuevas Directrices Curriculares. Este estudio, en fase de desarrollo, parte de una búsqueda sobre las nuevas prácticas periodísticas, que integra um grupo internacional de investigación sobre el tema. El objetivo es la investigatión de la convergencia en el campo y dicotomías entre la educación y la práctica de periodistas profesionales que trabajan en la redacción del portal web de noticias, Brasil Post. Es supuestos teóricos Bauman (1999), Wolton (2011) y Mattelart (2005) para entender el tiempo, el espacio y Nuevas Tecnologías de la Información y la Comunicación y está anclado en Figaro (2013) para discutir cómo hacer periodismo en el siglo XXI.

Palabras clave: La enseñanza del periodismo; Periodismo digital; Nuevas tecnologías de la información y la comunicación. 


\section{Introdução}

Nos dias de hoje, é possível notar os efeitos da globalização na formação das culturas e nos novos modos de pensar e agir em sociedade. Nunca na história da humanidade se teve tanta facilidade de acesso à informação e nunca se produziu tanto conhecimento, como atualmente. Frente às mudanças contemporâneas vigentes na cultura digital - novos formatos de construção do conhecimento e de aprendizagem, convergência dos veículos de comunicação, interatividade, instantaneidade da informação via mídias sociais etc. -, torna-se cada vez mais complexo sistematizar a configuração do jornalismo do século XXI. Como campo do conhecimento da grande área da Comunicação Social, os questionamentos acerca de sua legitimidade como instituição social do interesse público e de sua constituição como ciência tornam-se a cada dia mais latentes.

Diante dessa realidade, é natural constatar que o jornalista esteja passando por uma transição, tendo em vista que é indispensável à sociedade, porém, não na forma do profissional que conhecemos hoje (COSTA, 2008), pelo dinamismo e imediatismo da comunicação na internet, ambiente onde os cidadãos são também coprodutores da informação que vem à público. Enfatiza-se, portanto, nesse artigo o debate frente às ambivalências entre o ensino de Jornalismo, as perspectivas da práxis do jornalista na sociedade globalizada e o impacto da cultura digital, em um momento de adaptações dos cursos de Jornalismo no Brasil com as Novas Diretrizes Curriculares, homologadas pelo Ministério da Educação (MEC), por meio da Resolução no 1 de 27 de setembro de 2013. As instituições de educação superior tiveram um prazo de dois anos para implantar as medidas e adaptar as grades curriculares dos cursos de Jornalismo, que entram em vigor a partir de outubro de 2015.

Tem-se como objeto de estudo o portal de notícias Brasil Post $(B P)$, primeira versão sul-americana do Huffington Post (HF). Fundado em 2005 por Arianna Huffington e Kenneth Lerer, o HF é um projeto jornalístico "nascido dentro e para a internet e se converteu em um êxito de audiência incomparável [...] aparece na frente de todas as listas como uma das mais influentes empresas de comunicação americanas"' (ECHEVARRÍA, 2011, tradução nossa). Presente em diversos países do mundo, representa o reflexo dos novos tempos da sociedade.

1 "nacido en y para Internet, se convirtió en un éxito de audiencia incomparable [...] y ella aparece inevitablemente al frente de todas las listas como una de las más influyentes comunicadoras americanas" (ECHEVARRÍA, 2011). 
O artigo propõe alguns apontamentos acerca de uma investigação, em fase de desenvolvimento, sobre como o jornalista encontra respaldo nas Novas Diretrizes Curriculares do curso de Jornalismo frente às atuais perspectivas de atuação na sociedade da informação, considerando os aspectos que irão gerir a vida acadêmica desses profissionais daqui para frente. Esse ponto de partida é o que motiva a discussão apresentada neste estudo, que faz parte de uma pesquisa internacional sobre as novas práticas jornalísticas, decorrente de um convênio firmado entre a Université Lumière Lyon (França), pelo programa de pesquisa sobre Jornalismo na Era Digital (Journalisme à L'heure du Numérique - JADN) e, Universidade Federal do Paraná (UFPR), Universidade Positivo (UP) e Universidade Tuiuti do Paraná (UTP) por meio do Grupo de Pesquisa Comunicação e Cultura Ciber (Click).

$O$ recorte de estudo da pesquisa vai ao encontro do que evidencia Meditsch (2012) quando aponta a lacuna existente entre teoria e prática. Para o autor, a busca de uma adequação da teoria com a prática jornalística envolve conceitos, professores - teóricos e práticos - e os formandos que, em seus trabalhos de conclusão de curso, "reclamavam da impossibilidade de exercitarem a visão crítica da sociedade, que receberam nas disciplinas teóricas, no momento em que vão assumir o papel social de jornalistas" (MEDITSCH, 2012, p. 30).

\section{A sociedade globalizada, o espaço, o tempo e a comunicação na era digital}

Constatar que a imprensa caminha para um ambiente inovador, é pensar também qual o papel do jornalista nesse lugar e como ele percebe as mudanças na sociedade contemporânea, a diversidade cultural e suas influências em um mundo cada vez mais tecnológico. $\mathrm{O}$ jornalismo que conhecemos hoje com as sociedades democráticas, com raízes no século XVIII, quando se verificou o desenvolvimento do primeiro mass media, enfrenta atualmente novos desafios com a globalização e o ciberespaço. As mudanças são estruturais, embora os valores identificados com a expansão dos jornais no século XIX prevaleçam até hoje: "a notícia, a procura da verdade, a independência, a objetividade, e uma noção de serviço ao público - uma constelação de ideias que dá forma a uma nova visão do 'polo intelectual' do campo jornalístico" (TRAQUINA, 2012, p. 34). Assim, nesse mesmo século, tem-se o fortalecimento de um novo grupo social - os jornalistas. 
Com sua função consolidada, o jornalista e/ou o Jornalismo se veem, atualmente, em tempos e espaços diferenciados. A globalização, o local e o global, ou a glocalização, esta última definida por Mattelart (2005), interferem no modo de vida das pessoas, nos seus hábitos e na forma de se relacionarem, assim como, no modo de consumirem informação. Para Bauman (1999, p. 7), o fenômeno da globalização revela raízes e consequências sociais. Examinar causas e consequências da compreensão tempo/espaço leva à compreensão de que os mesmos são diferenciados e diferenciadores. "Ser local num mundo globalizado é sinal de provação e degradação social" (BAUMAN, 1999, p. 8). Esta constatação evidencia questões diretamente relacionadas ao universo jornalístico hoje, momento em que a informação e o saber (LÉVY, 1999) se deslocam em um universo virtual e a concentração de poder, o deslocamento dos centros e decisões, encontram-se livres de restrições territoriais.

Bauman (1999, p. 13) utiliza o princípio de Albert J. Dunlap para localizar no tempo e espaço os fatores determinantes da vida em sociedade. O empresário Dunlap pregava que "A companhia pertence às pessoas que nela investem - não aos seus empregados, fornecedores ou à localidade em que se situa”. Tal perspectiva leva Bauman (1999) a consolidar sua percepção do fim de um mundo sem fronteiras, de proprietários ausentes, de liberdade de movimentos, e novas hierarquias sociais, políticas, econômicas e culturais em escala cada vez mais mundial. O poder, então, estaria ligado a uma mobilidade adquirida por pessoas que investem, com capital, fazendo surgir uma nova mobilidade sem amarras locais, que flutua livremente. A ligação entre poder, capital e liberdade sem limites, evidencia a diferença entre o território (a localidade), a vida real, e a ausência de limites espaciais. "As distâncias já não importam, ao passo que a ideia de uma fronteira geográfica é cada vez mais difícil de sustentar no 'mundo real"' (1999, p. 19).

Ensinar Jornalismo, fazer Jornalismo, ser jornalista em um mundo globalizado, requer compreensão desse espaço, agora ciberespaço, devido ao avanço tecnológico e da internet, nas últimas décadas, quando a sociedade se movimenta, ganha notoriedade e voz. Encontrar um ponto de equilíbrio que ajuste essa tríade em uma unidade ou processo até a formação profissional, torna-se indispensável, pois se faz necessário compreender o lugar em que es- 
ses processos ocorrem, assim como o comportamento das pessoas em um mundo conectado, economicamente transformado em uma sociedade da informação e do conhecimento.

Wolton (2011, p. 71) coloca o jornalista como intermediário indispensável nesse cenário, por possuir o monopólio da legitimação da informação-notícia em qualquer suporte. "Não há informação-notícia sem jornalistas para produzi-las e, principalmente, para dar-lhes legitimidade." O autor faz ressalvas a serem consideradas, quando discute a evolução tecnológica; o avanço dos sistemas de informação; o papel do receptor; da sociedade; e a função da comunidade acadêmica (neste caso, os cursos de Jornalismo) em um mundo globalizado. Para Wolton (2011), a revolução da informação esbarra em dois obstáculos: a comunicação e o conhecimento. "A abundância da informação cria imperativamente a necessidade de conhecimento para compreendê-la" (p. 71). Na onda da inovação e na tentativa de reinventar novas práticas jornalísticas, o autor sinaliza que também precisamos reinventar o direito à informação, numa época em que estamos nos perdendo em um oceano de informações e num momento em que se paira sobre o mundo a ideologia do "faça você mesmo". "Nada mais ingênuo e perigoso do que pensar que amanhã, graças aos sistemas de informação, cada um se tornará seu próprio jornalista, fazendo caducar a existência, os direitos e os deveres dessa profissão" (WOLTON, 2011, p. 71).

Avançando sobre essas questões, Bauman observa que nos territórios físicos insere-se um outro espaço cibernético do mundo humano com a internet, o que, por sua vez:

[...] emancipa certos seres humanos das restrições territoriais e torna extraterritoriais certos significados geradores de comunidade ao mesmo tempo que desnuda o território, no qual outras pessoas continuam sendo confinadas do seu significado e da sua capacidade de doar identidade. Para algumas pessoas ela augura uma liberdade sem precedentes face aos obstáculos físicos e uma capacidade inaudita de se mover e agir a distância. Para outras, pressagia a impossibilidade de domesticar e se apropriar da localidade da qual têm pouca chance de se libertar para mudar-se para outro lugar. Com 'as distâncias não significando mais nada', as localidades, separadas por distâncias, também perdem seu significado. Isso, no entanto, augura para alguns a liberdade face à criação de significado, mas para outros pressagia a falta de significado. Alguns podem agora 
mover-se para fora da localidade - qualquer localidade - quando quiserem. Outros observam, impotentes, a única localidade que habitam movendo-se sob seus pés (BAUMAN, 1999, p. 25).

A desterritorizalização de poder em Bauman aproxima-se do que Pierre Lévy (1999, p. 47) declara ser virtual: toda entidade "desterritorizalizada”, capaz de gerar diversas manifestações concretas em diferentes momentos e locais determinados, sem, contudo, estar ela mesma presa a um lugar ou tempo em particular. Quando encontra similaridade com o deslocamento do saber e, consequentemente, com a desterritorialização das bibliotecas, Lévy faz uma reflexão do futuro da educação e de formação na cibercultura. A hipótese, apresentada por Lévy (1999), é de que a cibercultura encontra-se ligada ao virtual e expressa o surgimento de um novo universal, diferente das formas culturais que vieram antes dele no sentido de que ele se constrói sobre a indeterminação de um sentido global qualquer. As tecnologias intelectuais (bancos de dados, hiperdocumentos, simulações, realidade virtuais) favorecem novas formas de acesso à informação e novos estilos de raciocínio e de conhecimento.

A partir do século XX, com a ampliação do mundo, a progressiva descoberta de sua diversidade, o crescimento cada vez mais rápido dos conhecimentos científicos e técnicos, o projeto de domínio do saber por um indivíduo ou por um pequeno grupo tornou-se cada vez mais ilusório. Hoje, tornou-se evidente, tangível para todos que o conhecimento passou definitivamente para o lado do intotalizável, do indomável (LÉVY, 1999, p. 161).

Lévy levanta a hipótese ou afirma sistematicamente que o portador direto do saber é o ciberespaço, a região dos mundos virtuais, por meio do qual as comunidades descobrem e constroem seus objetos e conhecem a si mesmas como coletivos inteligentes. Houve um deslocamento desse saber, que antes predominava nas comunidades, no ancião, no território. O saber passa da comunidade viva (nas sociedades anteriores à escrita), para o livro (aqui, é o intérprete quem domina o conhecimento) e chega aos sábios, aos cientistas (o saber é transmitido pelas bibliotecas). Para Lévy (1999, p. 164), o saber ocupa, agora, a região dos mundos virtuais, o ciberespaço 
A desterritorialização da biblioteca que assistimos hoje talvez não seja mais do que um prelúdio para a aparição de um quarto tipo de relação com o conhecimento. Por uma espécie de retorno em espiral à oralidade original, o saber poderia ser novamente transmitido pelas coletividades humanas vivas, e não mais por suportes separados fornecidos por intérpretes ou sábios. Apenas desta vez, contrariamente à oralidade arcaica, o portador direto do saber não seria mais a comunidade física e sua memória carnal, mas o ciberespaço, a região dos mundos virtuais, por meio do qual as comunidades descobrem e constroem seus objetos e conhecem a si mesmas como coletivos inteligentes.

Armand Mattelart (2005, p. 108-109) teoriza o conceito de desterritorialização em face de um "espaço pós-nacional”, com contornos indefinidos, em que o Estado-nação encontra o seu fim, uma vez que as "teorias do pós-moderno se unem, com esse propósito, às do gerenciamento global". Ao extrair o conceito de governamentalidade de Michel Foucault, Mattelart reforça o papel do Estado-nação, de ator estatal, a redefinir suas funções reguladoras enquanto representante do interesse coletivo, frente à "crescente interdependência dos sistemas nacionais - técnicos, científicos, econômicos culturais, sociopolíticos, civis ou militares [...]" e aproxima essa constatação ao poder de uma sociedade civil globalizada ou como denomina o autor, glocalizada. Neste caso, como sinalizou Bauman, e reforça Mattelart, com o pensamento de Braudel, "se consagra à análise da recomposição das hierarquias, toda uma escala de polos principais e secundários de irradiação midiáticos e culturais, mas também de dependências" (2005, p. 111).

Nações, cidades, bairros ou áreas rurais. A exemplo da competição à
qual se entregam os indivíduos entre si, a concorrência dos territó-
rios locais sob efeito do global qualifica alguns e desqualifica outros.
Uma vertente da realidade da globalização tutelada pela bem azeitada
noção administrativa de 'glocalização' (MATTELART, 2005, p. 111).

O mesmo se diga da crença no poder de uma sociedade civil global soberana, eletronicamente conectada, liberta das fronteiras e das grandes máquinas instituídas, enfrentando apenas os megagrupos transnacionais. É simultaneamente a partir dos Estados e fora deles que se constrói um espaço público embrionário de dimensão mundial. 
Diante da compreensão de que o espaço físico, entendido como território, salta para outro patamar com a "desterritorialização" desses espaços e, modifica o lugar do "saber" (LÉVY, 1999), do poder (BAUMAN, 1999) e do "espaço pós-nacional” (MATELLART, 2005), o Jornalismo contemporâneo já não habita um espaço físico e sua localidade transcende o espaço geográfico. Há duas décadas criou raízes quando ingressou no universo online com os portais de notícias na internet e, atualmente, com a evolução da sociedade e da comunicação, o Jornalismo se modifica a cada dia, inclusive na sua relação com o leitor e com a audiência, instâncias expressas nas Novas Diretrizes Curriculares do MEC.

Questões levantadas por Wolton (2011, p. 77) evidenciam o lugar da comunidade acadêmica nesse debate, uma vez que "a revolução da informação não invalida o conhecimento acadêmico ou científico”. Professores universitários não podem mais se esconder "numa torre de marfim aristocrática" e jornalistas não podem mais ignorar a profundidade da cultura e dos saberes acadêmicos.

O mundo acadêmico, da pesquisa e do conhecimento, apesar do que possa ser dito, tem sido esmagado nos últimos 30 anos pelo mundo da informação, da mídia, do jornalismo e dos acontecimentos. A informação não matou o conhecimento, mas o marginalizou, mesmo se o meio acadêmico tem uma parte de responsabilidade nisso. Tudo contribui para a marginalização do mundo da cultura na democratização da cultura de massa, na dominação das novas tecnologias e na espetacularização do jornalismo. A lógica das notícias, com sua velocidade, brevidade, lógica de competição e obsolescência das coisas e do tempo, engoliu o cultural e o saber científico. [...] A revolução da informação não invalida o conhecimento acadêmico ou científico. Para que serve ter acesso a todo tipo de informação se não dispomos de conhecimentos para fazer interpretações? Como compreender, por outro lado, o impacto das informações sobre os saberes e dos saberes sobre a informação se esses universos estiverem muito distantes um do outro? A ideologia da velocidade e do 'faça você mesmo' esbarra na espessura das culturas, da história e das sociedades (WOLTON, 2011, p. 76-77).

Essas são perspectivas que se abrem ao ensino do Jornalismo, levando em consideração a comunidade acadêmica (intelectuais, professores universitários) e os alunos (futuros jornalistas), o que coloca o mundo do conhecimento mais próximo do cotidiano. Também é 
preciso inserir neste espaço os enquadramentos culturais e ideológicos, tendo em vista que a globalização das trocas de informação e dos conhecimentos obriga que se preste atenção a outras culturas (WOLTON, 2011).

Os últimos 20 anos (final do século XX e este início do terceiro milênio) retratam uma transformação no modo de comunicar. A comunicação passou do analógico ao digital, interferindo, ainda que lentamente, no universo das redações, transformando as noções de tempo e espaço (BARBOSA, 2013). A utilização do "ao vivo", por exemplo, traz notoriedade ao fato noticiado, mesmo que o jornalista não esteja na cena do acontecimento e sua relação com o público seja outra. Wolton (2006) e Barbosa (2013) relatam como a evolução da informação trouxe o público para a cena da comunicação quando passa a ocupar o posto de produtor de conteúdos, "munidos com seus celulares que podem filmar as cenas extraordinárias de um mundo em crise, registra minuto a minuto aquilo que choca a sua retina e que poderá vir a chocar outras pessoas, elas também público dos meios de comunicação" (BARBOSA, 2013, p. 336).

\section{O jornalista e suas perspectivas de atuação no século XXI}

Perante as inúmeras possibilidades de atuação, ao jornalista dos dias de hoje, agente social e protagonista da comunicação pública, cabe perceber e relacionar as várias partes que compõe o acontecimento:

\footnotetext{
[...] que tenha a condição de reelaborar o que vem como um dado, reconhecer o que ainda está mal desenhado, com contornos borrados, construir uma visão que totalize os fatos, inter-relacionando todas as esferas da sociedade, percebendo que o que esta acontecendo em cada uma delas é resultado da dinâmica que faz com que todas interajam, dentro das possibilidades daquela formação social, naquele momento histórico, que, como dissemos, são características do conhecimento (BACCEGA, 2003, p. 36).
}

Apesar de a informação chegar mais facilmente por meio da interação ativa do público, por outro lado, os cuidados em relação aos critérios de valor e de apuração da notícia devem ser redobrados, pois é no campo da produção da notícia, pautado pelo imediatismo, que os valores encontram terreno para se manifestar. É nesse mesmo lugar que as escolhas individuais e institucionais do jornalista e do 
seu modo de produção/fazer jornalístico pautam o que será de conhecimento do coletivo/sociedade.

Tendo em vista que o campo da produção tem imbricado no seu "modus operandi" fatores que "fogem de controle", de ordem mercadológica e institucional, por exemplo, a apreensão sobre as particularidades do modo de fazer jornalismo é ainda maior a partir do entendimento de que, conforme afirma Baccega (2003, p. 26), o público interpreta somente aquilo que chega ao seu conhecimento, ou seja, aquilo que foi escolhido no âmbito da produção, levando em conta vários aspectos, sobretudo a orientação da empresa detentora daquela mídia.

Se é verdade que o receptor (enunciatário/enunciador) mobiliza seu universo cultural para interpretar o que aparece nos meios de comunicação, seja de que gênero for, também é verdade que temos de levar em conta em nossas reflexões a mediação, o filtro que antecede o que ele está vendo, ouvindo ou lendo: a mediação no campo da produção (BACCEGA, 2003, p. 26).

Segundo Meyer (2004, p. 244), os jornalistas, imersos do campo da produção, experimentam uma série de coisas, como tornar o conteúdo o mais chocante e bizarro possível, divulgar informação tão rápido que não sobra tempo para checar os fatos ou ainda "mesclar o conteúdo editorial à publicidade paga ou ao material de assessoria de imprensa, de forma tão imperceptível que o consumidor não tem consciência de estar recebendo uma mensagem comercial". Porém, o autor admite que embora essas ações, em geral, não sejam realizadas por jornalistas legítimos, "há uma quantidade suficiente de infrações altamente visíveis feitas por jornalistas para que a opinião pública considere a distinção bastante imperceptível".

Neste sentido, Moretzsohn (2007, p. 154) critica o ideal da transparência pregado pelo Jornalismo:

[...] de saída, esconde coisas importantes como os interesses empresariais dos próprios jornais e das fontes que os alimentam, e o processo de seleção das informações que nos são oferecidas. Além disso, sugere a necessidade de exposição imediata dos fatos, como se a simples exposição bastasse para esclarecer o público. Principalmente por causa do uso da imagem, remetendo a antiga ilusão de que 'ver' é compreender' (MORETZSOHN, 2007, p. 154). 
As reflexões levantadas apontam para o que Fígaro (2013) relata a respeito das mudanças no mercado de trabalho dos jornalistas:

As mudanças nos processos e rotinas produtivas, a concorrência global e as novas demandas dos consumidores têm profundas implicações para os profissionais do setor da comunicação. Implicações que vão do campo ético-profissional ao cultural e pessoal. Elas demandam respostas, gestão e planejamento ao nível político institucional (empresas, sindicatos, Estado, faculdades) (FÍGARO, 2013, p. 12).

Não é por menos que Fígaro (2013, p. 14) reflete que, no mundo de trabalho, o jornalista, além da capacidade de atuar em multiplataformas, deve ter domínio sobre aspectos estéticos e de conteúdo, ter "noções de marketing e de administração, visto que se prioriza a visão de negócios/mercadoria já inserida no produto cultural, por meio do tratamento dados às pautas e à segmentação do público".

Tais implicações que se colocam postas na atuação do jornalista refletem que esse profissional se encontra em um campo de contradições. Para Grohmann (2013, p. 246), os jornalistas encontram na sua prática profissional o que não querem, ou seja, valores e práticas que não reiteram os valores deontológicos: “[...] o jornalista se ilumina com esses valores, no entanto, não são esses valores que orientam a atividade real de trabalho". Frente a essas evidências sobre o ensino de Jornalismo e as atuais práticas jornalísticas, parte-se para o relato da proposta da pesquisa que tem como objeto de estudo o portal de notícias Brasil Post.

\section{O Portal de Notícias Brasil Post}

Para discorrer sobre o campo de convergências e dicotomias entre o ensino do jornalismo e a prática profissional dos jornalistas, adota-se como objeto de estudo o portal de notícias web Brasil Post (BP). Lançado no dia 28 de fevereiro de 2014, o BP é a primeira versão latino-americana do Huffington Post (HF), portal de notícias americano (inaugurado em maio de 2005), sediado em Nova York, com escritórios em Washington DC, Los Angeles e outras cidades no mundo todo. Fundado por Arianna Huffington e Kenneth Lerer, possui 14 edições internacionais: Estados Unidos, Brasil, Canadá, 
Alemanha, Espanha, França, Grécia, Índia, Itália, Japão, Coreia do Sul, Maghreb (com base na Tunísia), Reino Unido e Arábia. Comprado em fevereiro de 2011 pela América Online (AOL) por 315 milhões de dólares, hoje, "supera os números de publicações tradicionais americanas, como os do jornal The New York Times ${ }^{2}$, além de contar com uma equipe de 850 editores, repórteres e engenheiros e cerca de 100 mil colaboradores blogueiros não remunerados ${ }^{3}$.

Associado à Editora $\mathrm{Abril}^{4}$, o portal de notícias $B P$ possui uma equipe de doze pessoas, liderada pelo editor-chefe Diego Iraheta. Na matéria "Boas-vindas: apresentando o Brasil Post" (Brasil Post, 2014), Arianna Huffington afirma:

[...] a proposta para a versão brasileira é receber suas muitas vozes, políticos, empresários e acadêmicos, lado a lado com estudantes, ativistas e artistas, sem hierarquias. Será um portal onde todos os brasileiros poderão vir para compartilhar suas paixões ou simplesmente postar o que já estão escrevendo em seus próprios blogs, como canal de distribuição adicional (HUFFINGTON, 2014).

Em outra matéria, "12 questões para entender o Brasil Post" (Brasil Post, 2015), relata-se que o objetivo do portal é "procurar e selecionar o que há de mais bacana nessa multidão de vozes, para fornecer ao leitor uma curadoria desse conteúdo gerado espontaneamente". Uma das características mais predominantes do portal é o foco na interação, nos comentários e sugestões de leitores usados como ponto de partida para as matérias: "Hoje, todos somos produtores e consumidores de informação: interagimos, comentamos e nos engajamos com tudo o que vemos". Segundo Ricardo Anderáos, ex-diretor editorial do portal, na reportagem "Um ano de Brasil Post, nunca aprendi e me diverti tanto" (Brasil Post, 2015), "o resultado é que, desde 1 de janeiro de 2015, 5,5 milhões de pessoas visitaram o Brasil Post [...] E mais de 62\% desses visitantes consumiram nosso conteúdo em seus celulares".

Sabe-se que o público-alvo do HF e de suas versões pelo mundo é jovem e consumidor de dispositivos móveis. Conforme resultado do

2 Disponível em: <http://veja.abril.com.br/noticia/vida-digital/huffington-postchega-ao-pais-atras-do-sonho-brasileiro/> (04/09/2011). Acesso em: 12 ago. 2015

3 Disponível em: <http://www.brasilpost.com.br/arianna-huffington/huffpost-10anos_b_7231682.html> (07/05/2105). Acesso em: 24 set. 2015.

4 Editora brasileira, sediada em São Paulo e parte integrante do Grupo Abril, um dos maiores grupos de comunicação da América do Sul. 
relatório produzido pelo próprio portal - "Aumenta o número de visitantes de dispositivos móveis em 37\% após o lançamento do site reprojetado" - "alcançar o leitor que utiliza vários tipos de tela se tornou um aspecto cada vez mais importante da estratégia on-line da editora".

Diante do apresentado, o recorte de estudo dessa pesquisa pretende verificar: as Novas Práticas Jornalísticas e o dilema da formação profissional; as NTICS nas diretrizes curriculares (princípios, concepções e propostas); a formação dos jornalistas que atuam nas redações do $B P$ (características, fragilidades, desafios do ponto de vista da empresa e dos jornalistas). A partir desses objetivos, a pesquisa de caráter quali-quantitativa está divida em três momentos. O primeiro e atual estágio, refere-se ao levantamento de dados empíricos relacionados aos jornalistas que atuam no BP: perfil, funções desempenhadas, seleção dos profissionais, vínculo empregatício, formação e opinião sobre o ensino no curso de jornalismo. Para levantar essas informações, elaborou-se um formulário, já encaminhado à redação do $B P$. No segundo momento, pretende-se realizar uma entrevista com o editor-chefe, em 2015, Diego Iraheta, com o objetivo de obter informações sobre os desafios, dificuldades e aspectos positivos do dia a dia profissional, adequação dos jornalistas à proposta do $B P$, a participação de blogueiros na produção de conteúdo, interação com o público e demais observações. Por fim, pretende-se fazer uma visita à redação para afinar as questões em aberto, assim como realizar entrevistas pessoalmente com jornalistas, no intuito de confrontar as informações levantadas com os resultados obtidos pelos formulários.

\section{Considerações finais}

A formação do profissional jornalista no cenário brasileiro entra numa nova fase com a aprovação das Novas Diretrizes Curriculares que deverão entrar em vigor em 2015, em face da comunicação, campo em constante transformação na era tecnológica. Meditsch (2012) sinaliza que receptores e emissores encontram-se em um mesmo patamar e que o "fazer Jornalismo" enfrenta turbulências no mundo contemporâneo e eleva esse problema ao papel pedagógico do ensino e da função do Jornalismo em mediar esse processo.

Diante desse panorama da globalização, onde a informação passou a circular nas mãos de multidões e os modos de comunicação adquiriram novas formas, o jornalista, frente às regras da conver- 
gência digital, normas institucionais e em meio a um campo caracterizado pelo descompasso entre o ritmo da formação acadêmica e a realidade de mercado, protagoniza mudanças inerentes a sua própria perspectiva de atuação. Novas práticas de fazer jornalismo estão sobre as mesas das redações, ou melhor, nas mãos dos jornalistas, que, hoje, como esclarece Fígaro (2013), devem ter capacidade de atuar em multiplataformas, com vários tipos de mídia, ter domínio estético de conteúdo, noções comerciais e de marketing, independente da corporação de comunicação do qual façam parte.

Sob esse ponto de vista, os cursos de Jornalismo vão esbarrar em outro dilema, preparar um profissional/jornalista multimídia, que vai encontrar uma redação transformada e adaptada tecnologicamente, que produz conteúdos digitais e adaptados para canais de veiculação diversos. Neste horizonte, a popularidade e a democratização dos bens de produção e distribuição da informação influenciaram o fim das fronteiras territoriais, de proprietários ausentes, de liberdade de movimentos, e novas hierarquias sociais, políticas, econômicas em escala mundial.

Para lidar com tais frentes que se colocam postas nas sociedades contemporâneas, os apontamentos levantados nesse artigo acerca da pesquisa em desenvolvimento, poderão trazer à luz importantes contribuições para o estudo das novas práticas jornalísticas, ao ressaltar a necessidade de aproximação entre professores universitários e profissionais jornalistas, afim de que se amenize a dicotomia entre a teoria e prática, para que jornalistas formados sob uma perspectiva crítica dentro das Novas Diretrizes Curriculares possam de fato melhor se adaptar a mudanças do ofício de fazer jornalismo e contribuir para a formação do indivíduo em sociedade.

\section{Referências}

ANDERÁOS, Ricardo. Um ano de Brasil Post, nunca aprendi e me diverti tanto. Brasil Post, São Paulo, 28 jan. 2015. Disponível em: $<$ http://www.brasilpost.com.br/ricardo-anderaos/brasil-post-aniversario_b_6559198.html>. Acesso em: 18 set. 2015.

BACCEGA, Maria Aparecida. Televisão e Escola, uma medição possível? São Paulo: Editora Senac São Paulo, 2003. 
BARBOSA, Marialva. História da comunicação no Brasil. Petrópolis, RJ: Vozes, 2013.

BAUMAN, Zygmunt. Globalização: as consequências humanas. Tradução, Marcus Penchel. Rio de Janeiro: Zahar, 1999.

BRASIL POST. 12 Questões para entender o Brasil Post. São Paulo, 28 jan. 2015. Disponível em: <http://www.brasilpost.com.br/2015/01/28/ entenda-o-brasil-post_n_6551094.html>. Acesso em: 21 set. 2015.

COSTA, Carlos. Novas Tecnologias e o ensino de Jornalismo. In: Líbero, Cásper Líbero, a. XI, n. 22, dez. 2008, p. 9-20. Disponível em: $<$ http://www.revistas.univerciencia.org/index.php/libero/article/ view/6079/5544>. Acesso em: 23 ago. 2015.

ECHEVARRÍA, Borja. Comunicar es el nuevo entretenimiento de la gente. El País, Madri, 16 out. 2011. Disponível em: <http://tecnologia. elpais.com/tecnologia/2011/10/16/actualidad/1318755661_850215. html>. Acesso em: 08 ago. 2015.

FÍGARO, Roseli (org); GROHMANN, Rafael; NONATO, Claudia. As mudanças no mundo do trabalho do jornalista. São Paulo: Editora Atlas S.A, 2013.

GOOGLE. The Huffington Post aumenta o número de visitantes de dispositivos móveis em $\mathbf{3 7 \%}$ após o lançamento do site reprojetado. Disponível em: <http://static.googleusercontent.com/media/www. google.com.br/pt-BR/br/think/multiscreen/pdf/the-huffington-postmulti-screen-resources_case-studies.pdf>. Acesso em: 24 mai. 2015.

GROHMANN, Rafael. O Jornalista como Receptor. In: FÍGARO, Roseli (org). As mudanças no mundo de trabalho do jornalista. São Paulo: Editora Atlas S.A, 2013.

HUFFINGTON, Arianna. Comemorando os primeiros 10 anos do HuffPost olhando para os próximos 10. Brasil Post, São Paulo, 07 mai. 2015. Disponível em: <http://www.brasilpost.com.br/arianna-huffington/huffpost-10-anos_b_7231682.html>. Acesso em: 24 set. 2015. 
. Boas-vindas: apresentando o Brasil Post. Brasil Post, São Paulo, 28 jan. 2014. Disponível em: <http://www.brasilpost.com.br/arianna-huffington/boasvindas-apresentando-o_b_4676219.html $>$. Acesso em: 08 ago. 2015.

LÉVY, Pierre. Cibercultura. Tradução de Carlos Irineu da Costa. São Paulo: Ed. 34. 1999.

MATTELART, Armand. Diversidade cultural e mundialização. Tradução Marcos Marcionilo. São Paulo: Parábola, 2005.

MEDITSCH, Eduardo. Pedagogia e Pesquisa para o Jornalismo que está por vir: a função da universidade e os obstáculos para sua realização. Florianópolis, SC: Editora Insular, 2012

MEYER. Philip. Os jornais podem desaparecer? Como salvar o jornalismo na era da informação. São Paulo: Editora Contexto, 2007.

MORETZSOHN, Sílvia. Pensando contra os fatos - Jornalismo e Cotidiano: do senso comum ao senso crítico. Rio de Janeiro: Revan, 2007.

TRAQUINA, Nelson. Teorias do Jornalismo, porque as notícias são como são. Florianópolis: Insular, 3. ed. Ver. 2012.

VALLE, James Della. 'Huffington Post' chega ao país atrás do 'sonho brasileiro’. Veja, 04 set. 2011. Disponível em: <http://veja.abril.com. $\mathrm{br} /$ noticia/vida-digital/huffington-post-chega-ao-pais-atras-do-sonho -brasileiro/>. Acesso em: 12 ago. 2015.

WOLTON, Dominique. É preciso salvar a comunicação. Tradução Vanise Pereira Dresch. São Paulo: Paulus, 2006.

. Informar não é comunicar. Tradução de Juremir Machado da Silva. Porto Alegre: Sulina, 2011. 